\title{
Natural Law in Mencius and Aquinas
}

Richard Kim

Loyola University Chicago, rkim7@luc.edu

Follow this and additional works at: https://ecommons.luc.edu/philosophy_facpubs

Part of the Philosophy Commons

\section{Recommended Citation}

Kim, Richard. Natural Law in Mencius and Aquinas. Confucianism and Catholicism: Reinvigorating the Dialogue, , : 135-154, 2020. Retrieved from Loyola eCommons, Philosophy: Faculty Publications and Other Works,

This Book Chapter is brought to you for free and open access by the Faculty Publications and Other Works by Department at Loyola eCommons. It has been accepted for inclusion in Philosophy: Faculty Publications and Other Works by an authorized administrator of Loyola eCommons. For more information, please contact ecommons@luc.edu.

\section{(c) (1) () $\Theta$}

This work is licensed under a Creative Commons Attribution-Noncommercial-No Derivative Works 3.0 License. (c) University of Notre Dame Press, 2020. 


\title{
Natural Law in Mencius and Aquinas
}

\author{
RICHARD KIM
}

Indeed, when Gentiles, who do not have the law, do by nature things required by the law, they are a law for themselves, even though they do not have the law. They show that the requirements of the law are written on their hearts.

-Romans 2:14-15

But the function of the heart is to reflect. If it reflects, then it will get it. If it does not reflect, then it will not get it. This is what Heaven has given us.

-Mengzi 6A15

[N]atural law ... is nothing other than the imprint of God's light within us.

-Summa theologica I-II, Q. 91, Art. 2

The natural law theory of ethics is understood by many scholars as a distinctively Western moral theory, with roots stretching back to Aristotle and the Stoics, finding its culmination in the thoughts of St. Thomas Aquinas. In this chapter I argue that Mencius, arguably the most historically influential thinker in East Asia, also held a form of natural law theory. Despite the variety of divergent interpretations of Mencius - as 
role-based theorist (Ames), consequentialist (Im), sentimentalist (Liu), and virtue ethicist ( $\mathrm{Yu}$, Ivanhoe, Van Norden) - no scholar has, to my knowledge, suggested that Mencius holds a form of natural law theory. ${ }^{1}$ In this chapter we explore this possibility, with the hope of deepening our understanding of Mencius as well as sharpening our understanding of the natural law. However, what I say in this chapter doesn't preclude the possibility that Mencius and Aquinas also held some form of virtue ethics or even a kind of deontology, although more would need to be done to clarify the precise sense in which they represent these theories. My aim is to show that Mencius also held a form of natural law theory, rather than to deny that he (or Aquinas) held a hybrid theory.

To many contemporary moral philosophers, the theory of natural law is often dismissed as an outmoded moral system, relying on a defunct metaphysics and erroneous biology. I find this unfortunate, since the theory of natural law, considered in itself, offers a powerful framework for moral reflection and harmonizes a number of moral claims that philosophers of different stripes would happily endorse. Not only does it defend the authoritatively binding force of moral claims concerning obligations or rights endorsed by Kantians, but it also grounds morality in natural facts about human beings, upholding a sort of naturalism that Humeans may find more congenial than ethical intuitionism or divine command theory. And while the theistic elements that most natural law defenders are committed to would be unappealing to many contemporary philosophers, at the formal level, as we shall see, the nature of the role that the divine has within a theory of natural law seems largely left open and may play a less significant role than scholars typically assume. ${ }^{2}$ It is important to distinguish between a formal understanding of natural law and particular substantive conceptions of natural law. We will return to these points later.

In the next section I will outline the central features of natural law by examining Aquinas's theory. Then I will examine Mencius's moral views in light of this outline and will examine the extent to which Mencius's account can be properly understood as a natural law theory of morality. I will make the case that, on the basis of this outline, Mencius's view ought to be counted as a form of natural law theory. Then I will reflect on how the different conceptions of natural inclinations we find in Aquinas and Mencius highlight how our understanding of human 
nature cannot be detached from a broader normative framework. While there are many attractive features of the natural law theory of morality, my aim is not to defend it as a viable contemporary theory of ethics. To do so would require careful responses to a number of objections to the theory. Rather, given the purposes of this volume, I hope to illustrate how Mencius, one of the most historically influential Chinese philosophers, can be understood as espousing a moral theory defended by Aquinas, one of the most influential Catholic philosophers, and to highlight ways in which a comparative reflection on both thinkers can enrich our understanding of the natural law.

\section{What Is the Natural Law?}

The very term natural law can be confusing, and unfortunately, we find a range of different meanings in scholarly discussions. Instead of sifting through the variety of meanings that have been attached to this term, I will borrow an approach taken by Mark Murphy and examine the conception of natural law held by St. Thomas Aquinas, a figure widely accepted as a central representative of the natural law tradition in ethics. ${ }^{3}$ Almost every book or article that discusses the tradition of natural law ethics includes some mention or discussion of Aquinas. By taking Aquinas as a central representative of this tradition, we can mine his views to extract the core features of a natural law theory and then examine Mencius's ideas in light of those features. While not all natural law theorists will agree with Aquinas about what is essential to the natural law, it is reasonable to hold that a view that endorses all or most of the core features of Aquinas's natural law account has a legitimate claim to be counted as a form of natural law.

Consider the following description of natural law stated by Aquinas: "So since ... all the things subject to divine providence are regulated and measured by eternal law, it is clear that all things in some way participate in eternal law. More precisely, because eternal law is imprinted on them, they have inclinations toward their own proper acts and ends.... And the rational creature's mode of participation in the eternal law is called natural law."' The eternal law, briefly, is the set of immutable laws that are present in the divine mind of God that serve as the 
archetype of all creation. You might think of them as resembling Plato's forms, except that they are in the mind of God. ${ }^{5}$ This passage demonstrates Aquinas's view that not just human beings but all of creation is regulated by the eternal law of God. As Aquinas notes, "The eternal law is imprinted on them," so they all have "inclinations toward their own proper acts and ends." But the natural law is what pertains to the mode of participation in the eternal law for creatures with the capacity to reason and reflect. Human beings, then, like all other creatures, have certain proper inclinations and ends, but because of their rational power to direct themselves according to perceived reasons they achieve their ends in a rational manner.

It may be helpful to unpack the concept of "natural law" by inquiring separately into the concepts of "natural" and "law." Let's start with "natural." What is Aquinas's conception of nature? Aquinas draws upon the metaphysical-cum-biological framework set by Aristotle. He takes the natural world as exemplifying a certain structure or order-which explains its intelligibility - and understands each living organism as possessing a particular nature or form. The forms inherent in the oak tree, tiger, or whale determine the shape and trajectory of their basic life processes and determine the sorts of characteristic activities that constitute their life-form; the criteria for what counts as good, beneficial, or flourishing for a living entity are fixed by the nature or form that the entity possesses.

Aquinas extends the ideas of Aristotle by being more explicit about the natural inclinations that constitute human nature. He explicitly identifies, for example, four natural inclinations that constitute the human life-form: the preservation of life, procreation, the drive for knowledge, and the inclination to live in a community (ST I-II, Q. 94, Art. 2). As Aquinas claims, the precepts of the natural law correspond to these natural inclinations: "It follows that all the things man has a natural inclination toward are such that reason naturally apprehends them as goods.... Therefore, there is an ordering of the precepts of the natural law that corresponds to the ordering of the natural inclinations" (ST I-II, Q. 94, Art. 2). Of course, how exactly we should develop and shape these inclinations can only be understood in light of one's particular context; individual temperament, abilities, and culture all have a critical role to play. But at a fairly general level, we can mark out the basic inclinations and ends that all human beings must value if they are to lead flourishing lives. 
What about the concept of "law"? Aquinas offers the following account: "Law is (a) an ordering [ordinatio] by reason, (b) directed toward the common good, (c) made by one who is in charge of the community, and (d) promulgated" (ST I-II, Q. 90, Art. 4). On Aquinas's view, laws are not the arbitrary products of a ruler: they have a function, which is to provide standards of conduct that direct human beings toward their good. An essential feature of law is that it carries binding force: "Law is a certain rule and measure of acts in accord with which one is either induced to act or restrained from acting. For 'law' $[l e x]$ is derived from 'to bind' [ligare], since law obligates [obligare] one to act" (ST I-II, Q. 90, Art. 1).

Laws are standards, rules, or measures of human conduct that generate requirements for action. On Aquinas's view, the obligatory force of laws is ultimately derived from their conduciveness to human flourishing and the common good, which give laws their point. So the natural law is a type of rational and normative standard that is derived from the natural inclinations and ends determined by human nature. They are distinct from what Aquinas calls "human laws" like traffic laws, since human laws can be revised or discarded depending on the situation. The natural law is not determined by human willing but is fixed by the nature of human beings. In this way, while God is the creator of human beings, the binding force of the natural law is generated, not from the will or commands of God, but by the goods and ends that are determined by human nature. ${ }^{6}$ Aquinas's view, therefore, counts as a form of ethical naturalism (though clearly distinct from the sort of naturalism we find in Hume) and is in stark opposition to the voluntarist theories of morality proposed by later thinkers like William of Ockham and Samuel Pufendorf. According to the voluntarists, only the legislative will of God can generate moral obligations, whereas for Aquinas facts about what is necessary for achieving the human good can generate moral duties. To illustrate this difference, consider a concrete example: the obligation to refrain from murder. On Aquinas's account, this obligation is derived from the basic inclination toward the preservation of life. Taking someone's life (in the absence of some overriding consideration) directly conflicts with this inclination and undercuts a crucial (and obvious) condition of flourishing. On the voluntarist picture, however, the obligation to refrain from murder is derived from the command of God not to murder. Even if the voluntarist were to grant 
Aquinas's claim that murder goes against a natural inclination inherent in human nature, the duty to refrain from murder could be generated only by God's command; without the legislative act of God, such an obligation would simply not exist on the voluntarist account. This is not to say that the voluntarist must deny that the preservation of life is not a natural good, but there would be no moral obligation attached to the preservation of life without some divine command?

\section{Mencius's Account of Heaven (tian) and Human Nature}

Let us now turn to Mencius's account of heaven and human nature. While it will not be possible to discuss all the details of Mencius's view, I will outline some of his core ideas that are relevant to our discussion.

Most scholars are familiar with Mencius's claim that "human nature is good." But it is generally acknowledged by scholars that he meant by this not that all human beings or even most human beings are morally good but rather that human beings are endowed by Heaven (tian) with a certain nature that is disposed toward goodness. Mencius identifies four basic inclinations or feelings, often translated as "sprouts," which are constitutive of human nature that can be cultivated into distinctive virtues:

We can see that if one is without the feeling of compassion, one is not human. If one is without the feeling of disdain, one is not human. If one is without the feeling of deference, one is not human. If one is without the feeling of approval and disapproval, one is not human. The feeling of compassion is the sprout of benevolence. The feeling of disdain is the sprout of righteousness. The feeling of deference is the sprout of propriety. The feeling of approval and disapproval is the sprout of wisdom. People having these four sprouts is like their having four limbs. To have these four sprouts, yet to claim that one is incapable [of virtue], is to steal from oneself. ${ }^{8}$

To achieve a flourishing human life, we must develop these basic aspects of our nature (i.e., the "sprouts"), through the process of moral selfcultivation. Here we see that Mencius, like Aquinas, also accepts human nature as the foundation for human flourishing; both thinkers identify 
a number of natural inclinations that must be properly developed to achieve the good life. Another interesting similarity between the two thinkers can be understood by appreciating Mencius's use of agricultural metaphors to illustrate the process of moral self-cultivation. Mencius likens the cultivation of the moral self to the cultivation of barley seeds (Mencius 6A7). What the moral sprouts and the barley seeds share in common is the possession of a potential that needs to be actualized through both human effort and judicious manipulation of the environment. ${ }^{10}$ There is a teleological structure to their development, which must be followed in order to achieve complete virtue. Aquinas takes a strikingly similar line-drawing upon the ideas of Aristotle-by emphasizing the importance of what completes or perfects an organism as determined by a thing's nature. What is perfective of the barley seed, in Aquinas's account, is its fulfillment of the potential to become mature barley; similarly, what is perfective of human beings is the fulfillment of the potential to become rational, virtuous agents. Of course, numerous differences remain between Aquinas and Mencius regarding the nature of the virtues and the sorts of characteristic activities that are most essential to human life. Nevertheless we find them taking similar approaches with regard to the role and structure of certain foundational concepts including virtue, nature, and flourishing.

So human nature, on Mencius's view, determines human flourishing. But Mencius also appeals to Heaven in his discussion of nature. Quoting the Book of Odes (Shijing), a collection of classical Chinese poetry, Mencius says:

Heaven gives birth to the teeming people.

If there is a thing, there is a norm.

This is the constant people cleave to.

They are fond of this beautiful Virtue.

(Mengzi 6A6)

In a related passage Mencius remarks: "To fully fathom one's heart is to understand one's nature. To understand one's nature is to understand Heaven. To preserve one's heart and nourish one's nature is the way to serve Heaven" (Mengzi 7A1). From these two passages we can draw the following points: (a) Heaven endowed human beings with their given nature; (b) Heaven enjoys a certain authority; (c) by fulfilling our nature, 
we serve Heaven. While Heaven, for Mencius, does not appear to have the sort of personal interest in individual human beings exemplified by the God of Judaism, Islam, and Christianity, Heaven possesses a will and a plan that is directed toward the common good. As Philip Ivanhoe remarks: "According to Mengzi [Mencius], Heaven has arranged things in the world in such a way that for each thing there is a proper role and function and the general scope and particular parts of this grand plan are things that human beings can and must come to understand." Although the will of Heaven is not always made clear to us, Mencius sees in human nature the imprint of Heaven's work, and by understanding human nature as oriented toward the life of virtue Mencius comes to see Heaven's will as directed toward the good. ${ }^{12}$

\section{Does Mencius Hold a Natural Law Theory?}

While acknowledging that much more needs to be said about both Aquinas's and Mencius's accounts of human nature, normativity, and God or Heaven, let us turn to the central question of this chapter: Does Mencius hold a natural law theory of morality?

To answer this question I want to propose five conditions, satisfied by Aquinas's account of natural law, that will help determine whether a moral position counts as a form of natural law. We can understand these conditions in the form of the following four questions: (1) Does the theory ground human goods in human nature? (2) Are moral considerations ultimately grounded in facts about human well-being? (3) Is morality backed by God or a deity? (4) Is morality authoritative over all human beings? (5) Is morality naturally knowable by all human beings? While I don't claim this to be an exhaustive list, I think it captures the core ideas of Aquinas's theory.

But how many of these conditions does a theory have to meet to count as a theory of natural law on Aquinas's view? I don't think there is a clean answer to this question, but a theory that meets all of them or close to all of them should count as a form of natural law.

Let us briefly go through each question. First, does the proposed theory ground human goods in human nature? This question is important since a theory of natural law needs the moral law and the relevant human goods to be grounded in facts about the nature of human beings. By grounding human goods and normativity in human nature- 
particularly in the moral sprouts of human nature-Mencius's view would answer positively on this question.

Second, are moral considerations ultimately grounded in facts about human well-being? Although the natural law tradition endorses the existence of moral obligations and rights, these are conceived as inseparable from considerations of human flourishing. Unlike the Kantian picture, morality is not a sui generis category that carries its normative force independent from truths concerning human well-being but is instead ultimately derived from facts about human nature that determine the sort of life that is good for humans. If we assume-quite plausibly - that the moral duties or obligations Mencius would endorse are closely tied to the development of the virtues through the cultivation of moral sprouts embedded in human nature, I think there is good reason to take Mencius as also understanding the normative force of moral obligations as inextricably bound up with considerations of human well-being, construed broadly.

Next: Is morality backed by God or a deity, in the sense that the moral laws have been sanctioned or approved by a divine being? This question affirms the point that the natural law is a form of "law" and appears to require a lawgiver. As Aquinas describes it, the natural law is participation in the eternal law, which constitutes the divine ideas and plans of God. This issue about the relevant role that the lawgiver plays is actually quite complicated for Aquinas, and I will return to this point below, but it is clear that for Aquinas the natural law ultimately finds its source in the eternal law, which exists in the mind of God. But what about Mencius? Given Mencius's view that human nature, endowed by Heaven, is directed toward the good, and that we "serve Heaven" by nourishing our nature, it seems clear that Heaven at least approves of developing our nature. As discussed above, for Mencius, developing our nature is most centrally about nourishing the moral sprouts so that they develop into the Confucian virtues of benevolence, righteousness, ritual propriety, and wisdom. Since for Mencius the proper aim of morality is developing into a Confucian sage exemplifying these virtues, it is clear that morality enjoys Heaven's approval.

While one might agree that Mencius affirms the view that Heaven sanctions Confucian morality, one might wonder how this is ultimately connected to the notion of the natural law, since we don't find Mencius employing the sort of legal terminology found in Aquinas. Moreover, 
Mencius's conception of morality centers on the development of a certain ethical character, rather than rules, duties, or obligations. (Aquinas too, discusses the virtues at much greater length compared to his treatment of the natural law.) Regarding this last point, while we do find in Aquinas the endorsement of exceptionless moral rules (e.g., the Ten Commandments), Aquinas understands goodness as having priority over rightness, as revealed in his first principle of practical reason: "Good is to be done and pursued, bad avoided" (ST I-II, Q. 94, Art. 2). Moral rules and obligations, for Aquinas, are derived from their connections to human goods. Of course, some of these rules are simply revealed to us by God, but Aquinas would claim that even these rules are given their point by connections to human flourishing. Going back to Mencius, while he doesn't offer anything like a list of rules or obligations to live by, he does endorse certain general rules (which always require proper moral perception for correct application). Commenting on the sages, Mencius says, "If any could obtain all under Heaven by performing one unrighteous deed, or killing one innocent person, he would not do it" (Mengzi 2A2). But as with Aquinas, I think we can also understand such rules as grounded in considerations of human goods, in this case, in the virtue of righteousness, which is necessary for Confucian well-being.

Nevertheless, nowhere does Mencius employ a term that resembles Aquinas's concept of "law."13 But as will be discussed further below, for Aquinas "law" is simply a rule of action directed toward the common good that is promulgated by a competent authority (ST I-II, Q. 90, Art. 4). The kinds of rules that Mencius would have endorsed are, as I understand him, directed toward the Confucian conception of the good, which is ultimately grounded in the development of the moral sprouts embedded in human nature. And since it is Heaven that has given us our nature, the general rules of morality can also be understood as at least indirectly given by Heaven. ${ }^{14}$

Given his appeals to Heaven, we can take Mencius as also accepting morality as sanctioned by Heaven, particularly, through the nature that Heaven has given us to follow. So while we can't say that Mencius takes morality as backed by a lawgiver in precisely the same way that Aquinas does, Mencius does appeal to Heaven to at least partially justify his understanding of the goodness of human nature. One reason Mencius would offer for affirming the goodness of human nature is that nature is the product not of arbitrary processes but of Heaven's will and that Heaven as noted earlier, works for the good. 
The fourth question asks whether morality is authoritative over all human beings. Mencius claims that the possession of the moral sprouts of human nature is like the possession of arms and legs in humans: "People having these four sprouts is like their having four limbs" (Mengzi 2A6). Just as missing a limb indicates a bodily defect, Mencius would claim that missing a moral sprout indicates a moral defect..$^{15}$ This standard, Mencius would insist, applies to all human beings.

Finally, we turn to whether morality is naturally knowable by all human beings. This is an important condition, since one of the basic ideas of the natural law is that human beings have the natural capacity (when developed under proper conditions) to grasp the basic tenets of the natural law. Mencius clearly endorses this view, since he believes that the sprouts are inherent in human nature and that all human beings possess a heart that can reflect on and understand the way to become a "great person" and avoid becoming a "petty person": "It is not the function of the ears and eyes to reflect, and they are misled by things. Things interact with other things and simply lead them along. But the function of the heart is to reflect. If it reflects, then it will get it. If it does not reflect, then it will not get it. This is what Heaven has given us. If one first takes one's stand on what is greater, then what is lesser will not be able to snatch it away" (Mengzi 6A14-15). This reflective capacity provides all normal human beings with the capacity to make evaluative judgments and grasp basic moral requirements. But training is necessary to develop and sharpen this evaluative capacity, in the way that our natural linguistic capacity also requires considerable exposure and exercise to develop.

Table 6.1 summarizes the above discussion of Aquinas's and Mencius's views on natural law.

Table 6.1. A Comparison between Mencius and Aquinas on the Features of Natural Law

\begin{tabular}{|c|c|c|}
\hline & Aquinas & Mencius \\
\hline Does theory ground human goods in human nature? & Yes & Yes \\
\hline Are moral considerations grounded in well-being? & Yes & Yes \\
\hline Is morality backed by God or a deity? & Yes & $\begin{array}{l}\text { In some } \\
\text { sense }\end{array}$ \\
\hline Is morality naturally authoritative over all human beings? & Yes & Yes \\
\hline Is morality naturally knowable by all human beings? & Yes & Yes \\
\hline
\end{tabular}


Before we move on, it may be worth addressing a worry that was briefly noted earlier, which is that the very concept of natural law requires legislative acts, which seem to be missing in Mencius's account. But on Aquinas's understanding of the natural law, the legislative will of a divine lawgiver plays a less substantial role than one might think. Consider the following point made by T. H. Irwin: "The relevant features of law do not essentially involve legislation and a legislator; they can all be understood non-legislatively. [Aquinas] believes that natural law contains rules, commands, and action-guiding requirements, but he does not argue that law essentially consists in commands that are expressions of the will of a legislator. In his view, natural law follows from the goaldirected agency characteristic of human beings." 16

One might be worried that Irwin's view seems too deflationary and that Aquinas takes the divine will to play a much more substantial role in his theory of natural law. By this understanding, one might think it more apt to call Aquinas's view a theory of natural "norms or rules."17 Undoubtedly Aquinas takes God as the ultimate source of morality, since God is the first cause and sustains everything, with nothing escaping the providential intentions of God. However, I think Irwin is right that for Aquinas, once human beings with their given natures are created by God, the content of morality is determined by natural facts. Moreover, we do sometimes employ the term law to discuss aspects of reality without necessarily thinking of law as being instituted by a legislator, for example, in talking about the "laws" of physics or chemistry, suggesting that our contemporary usage of the term may be broader than we might think. I would, however, acknowledge that room needs to be made for the background metaphysics that makes natural law a kind of law. Here, Mencius's views about the authority of Heaven and his view that we should serve Heaven by fulfilling our nature seem to me to offer enough divine metaphysical backing to sustain the obligatory force of law as Aquinas envisions it. ${ }^{18}$ This may strike some readers as making the concept of "natural law" too broad, but given Aquinas's own fairly wide understanding, this seems to me a warranted interpretation.

Reflections on the List of Natural Inclinations in Aquinas and Mencius

If, as I have tried to show, Mencius's moral theory counts as a natural law theory of morality, how might it help advance our understanding of 
the natural law? One way that Mencius may help contribute to our understanding of natural law is by drawing attention to aspects of human nature that are not explicitly discussed in Aquinas. Recall that Aquinas lists four natural inclinations in his discussion of the natural law: (1) self-preservation, (2) procreation, (3) knowledge, and (4) life in society (ST I-II, Q. 94, Art. 2). Mencius, however, identifies the following four natural inclinations (or "sprouts") as central to our understanding of human nature: (1) compassion, (2) disdain, (3) deference, (4) approval and disapproval (Mencius 2A6). Both Aquinas and Mencius take these various inclinations as directing us toward significant human goods that need to be properly developed or shaped in order to achieve human flourishing. One clear difference is that Aquinas's list is broader than the list of Mencius in that it contains not only those natural inclinations that are unique to human beings, such as the inclination toward knowledge and life in society (although one could make the case that both exist in other animals, albeit in more primitive forms), but also those inclinations shared by all living organisms, such as self-preservation, and the inclinations shared by all animals, such as the drive to reproduce. Mencius, however, is more concerned with socio-moral inclinations that are crucial for life in community. ${ }^{19}$ The feeling of compassion draws us to be concerned about the welfare of others; the feeling of disdain alerts us to the shamefulness of certain actions; the feeling of deference furnishes us with a sense of respect for others and toward ritual practices; the feeling of approval and disapproval allows us to evaluate the character of others and to understand how to develop other virtues. Each of these basic inclinations, after a long process of self-cultivation, will develop into a particular virtue. Undoubtedly, much more discussion is needed to flesh out the details regarding these different natural inclinations and how they tend to operate in a range of situations. At the least, Mencius here draws our attention to a number of basic natural moral inclinations that are simply absent in Aquinas's discussion of the natural law. This is not to say that Aquinas's list of inclinations is incompatible with that of Mencius; we might think of Mencius's four inclinations as more concrete instances of Aquinas's more general inclination toward life in society.

I think that two points are highlighted by reflection on the natural inclinations in Aquinas and Mencius. The first is that while a case can be made for the universality of the natural inclinations identified by both Aquinas and Mencius, the list of the natural inclinations is clearly not the product of bare empirical observations but is connected to the values 
and ideals and the larger moral framework endorsed by each thinker. Aquinas's understanding of the natural inclinations, for example, is informed by his Aristotelian understanding of the human soul as exhibiting powers of the intellect and will, along with sensory and nutritive capacities. Moreover, on Aquinas's view, one can achieve perfect happiness, and therefore perfect virtue, only with the aid of divine grace. In Mencius we can see each natural inclination as the base from which one develops the set of virtues that will enable one to live an excellent life within a Confucian community. This is especially clear in the sprout of deference, which leads to the virtue of ritual propriety and proper respect for the elderly. In this way, while Aquinas identifies natural inclinations that are more universally applicable, Mencius's account of the natural inclinations is much more closely connected to the Confucian way of life. The point is that although both thinkers can certainly make a case for the existence of these natural inclinations by appealing to empirical observations, their normative significance cannot be fully understood without an appeal to the broader ethical framework within which each of these inclinations gains its role and significance.

What the above remarks also indicate is that neither Aquinas nor Mencius employs a purely scientific or non-normative understanding of human nature. While both thinkers draw attention to observational experience in supporting their views, their understandings of human nature and the natural inclinations are developed in light of the values and ideals that shape their understandings of both human flourishing and the common good. ${ }^{20}$ This is why the common objection to natural law ethics - that human beings are afflicted by various immoral or vicious tendencies - does not carry much force for these thinkers. ${ }^{21}$ Now, if one has a purely scientific understanding of human nature, as solely constituted by the most widespread dispositions and tendencies, then such an objection is devastating. But any sophisticated moral framework that invokes considerations about human nature will understand human nature in a holistic way, as incorporating those dispositions and inclinations that play an important role in the characteristic activities and functions that are necessary for achieving a flourishing life. So, for example, while human beings undeniably have widespread immoral tendencies toward envy and violence, such dispositions, from the point of view of the common good and individual well-being, are detrimental for us and so would not fall within the conception of human nature that 
is closely connected to the concept of the human good. Another point one could also make is that such dispositions are not basic or fundamental to human nature but rather are outgrowths of other, more fundamental aspects of human nature such as our natural inclination to like and be attached to those who are familiar to us. Such an inclination, one might argue, is not in itself morally bad, although it could lead to vicious traits like racism. On the other hand, even though virtues like courage, generosity, or gratitude may not be as widespread as vicious tendencies (although this is a point that needs to be settled through empirical research), they can be shown to play a beneficial role in human lives by building stronger, peaceful communities and contributing to our overall well-being.

CONTEMPORARY Western moral philosophers tend not to take seriously the importance of learning from, let alone understanding, traditions such as Confucianism and Catholicism. One possible source of this dismissive attitude is the fear that by being adherents of a particular tradition one becomes rigidly committed to the norms and values of that tradition, disabling one from making autonomous judgments that are free from the strong commitments of a particular worldview. While this is an understandable concern, one point worth considering is that we all bring to the philosophical table a set of commitments and values and that none of us are completely free from the influences of culture and society, as well as our own particular set of life experiences. (Would we really want to be completely detached from such influences?) Moreover, one could make a serious case that belonging to a community or tradition with shared values and commitments offers a better social, moral, and intellectual environment for making progress. Even the secular philosopher benefits much from being a member of a wider philosophical community, which promotes certain values and standards (which one might not always find congenial) that help to sustain philosophical dialogue. This is certainly true in science, where a scientific community that works with the shared values of cooperation, open-mindedness, and rigorous experimentation will be in a much better position to build on past research and facilitate progress. Numerous other disciplines could also be cited in support of this thought: architecture, jazz, portrait painting, architecture, and chess. Each discipline involves a community with a common standard that draws upon past achievements. Creativity 
and innovation - crucial for the success of any discipline-are not generated in a vacuum but develop within a particular ongoing tradition of thought and practice. Criticisms and revisions certainly have an essential role to play in the development of a tradition, but even they are made against the background of a shared framework, constituted by shared goals and ends.

I hope these remarks draw attention to reasons why traditions play such an important and indispensable role in our lives. On the other hand, as noted earlier, there is an understandable fear that deep commitments to traditions can generate a fanatical and intolerant attitude that has been at times a source of hatred and violence. What we need, then, are traditions that are capable of sustaining and nourishing the lives of those who occupy the globalized, modern society that we inhabit today. Here I would argue that a commitment to a form of natural law tradition offers a helpful way of meeting this demand, especially by drawing attention to the fact that we share a common nature that undergirds the basic human rights that can be enjoyed by all human beings. For despite the misapplication and abuse of the concept of human nature that we unfortunately find in history, the recognition of our shared humanity can serve as a powerful moral resource for anchoring the respectful attitude that allows us not only to tolerate but to positively appreciate the commitments and values of other traditions.

Returning to Mencius and Aquinas, we see that both thinkers were profoundly influenced by their respective traditions, although because of the importance they placed on understanding human nature they were also keen observers of human behavior in all its varieties, virtues, and vices. And while they disagree in significant ways about the ultimate ends of human life (contemplative union with God for Aquinas, a sagely life within a Confucian community for Mencius), they help us identify certain normatively significant aspects of human nature that will help us recognize those basic inclinations and needs to which we must carefully attend if we are to realize both intrapersonal and interpersonal flourishing. As noted earlier, while Aquinas identifies broader natural inclinations, such as sociality, that we can clearly recognize as necessary for living any recognizably human life, Mencius - from a distinctively Confucian perspective-draws attention to moral dispositions that he takes as necessary for a life that goes well. And while Mencius's conception of 
the proper development of these dispositions is indeed inseparable from his Confucian ideals and values, I believe that in important ways even those of us living in contemporary America can recognize that such emotional dispositions as compassion or shame are powerful sources of human motivation and can be directed and shaped in ways that promote well-being.

While few of us would accept every value or ideal articulated by these two profound thinkers, I am confident that their insights, especially concerning the kinds of creatures we are and the sorts of individual and communal goods necessary for achieving the good life, will strike us as remarkably relevant to our lives. For Mencius and Aquinas, this last point would be unsurprising.

\section{NOTES}

1. For a role-based interpretation, see Ames (2011); for a consequentialist interpretation, see $\operatorname{Im}$ (2011); for a sentimentalist interpretation, see Liu (2002); for virtue ethical interpretations, see Yu (2007), Van Norden (2007), and Ivanhoe (2000).

2. Of course, as Michael Slater has pointed out to me, most contemporary naturalists would find even this aspect of natural law ethics problematic. At the end of the day there will remain substantive disagreements about the need for the divine and about the metaphysics of value. By no means am I claiming that a strict Humean naturalist and a Thomistic natural law theorist can ultimately agree on fundamental metaethical and normative issues.

3. Murphy (2011).

4. Thomas Aquinas, Summa theologica (hereafter ST) I-II, Q. 91, Art. 2. All citations to this work are to Freddoso's translation (Aquinas 2009) and are subsequently given parenthetically in the text.

5. There are difficult issues here about how forms can exist in the mind of God and other metaphysical questions concerning the nature of God. Given the goals of this chapter, it will not be necessary to discuss these issues in detail.

6. But since God, on Aquinas's view, creates natures (including the nature of humans) through divine willing, isn't the binding force of the natural law still, perhaps indirectly, determined by divine command? I don't see a problem with this characterization, but what is clear is that once God has created human beings constituted with a particular nature, what determines their proper end and their flourishing is fixed. Not even God could simply will that a radically different life was good for human beings unless God changed human nature radically, in which case the category of "human being" might no longer apply. Contrast this position with that of a divine voluntarist like William of Ockham, who thought 
that it was metaphysically possible for God to command us to murder, steal, or even hate God. Aquinas would deny that such commands are metaphysically possible, since such commands would not accord with the human good as determined by human nature.

7. We find in the voluntarists a sharp division between natural and moral goodness that natural law theorists like Aquinas or eudaimonists like Aristotle would deny. This sharp separation between the natural and the moral continues to exert a powerful influence on modern moral philosophy, for example, in contemporary discussions of egoism and altruism.

8. Mengzi 2A6. All citations of the Mengzi (Mencius) are from Van Norden's (2008) translation and are subsequently given parenthetically in the text.

9. For a lucid and helpful discussion of the importance of the agricultural metaphors in Mencius and also an account of Mencius's overall philosophical project, see Ivanhoe (2000, 15-23).

10. This is not to say that Mencius's sprouts are completely dormant; they are to varying degrees active.

11. Ivanhoe $(2007,216)$.

12. There is scholarly dispute concerning the nature of Heaven (tian): for example, whether Heaven is a transcendent or immanent being, or whether Heaven is personal or impersonal. These issues, while important, are not directly relevant to the purposes of this chapter, so I will not address them here. For what I take to be the most plausible interpretations on these issues, see Puett (2002); Ivanhoe (2007); and Cline (2013).

13. Additionally, there is an antilegalist strand in Confucianism that takes laws as problematic because (a) human beings tend to shirk external constraints, and (b) human life is too complex to admit of laws that can be applied in all cases. While I think the Confucian tradition focuses on the cultivation of character for these reasons, I think there is enough evidence that early Confucians believed there are general moral rules grounded in considerations of virtue and flourishing, such as rules against murder and theft. And even Aquinas finds ways of accommodating hard cases: for example, when someone steals to feed his starving family. In such a case, Aquinas argues, the surplus property of the wealthy becomes "common property" because of human need, so there is no theft taking place in such cases (ST II-II Q. 66, Art. 7). Similarly the Confucian tradition readily acknowledges difficult cases and the need to use wise judgments to appropriately weigh different values. I thank an anonymous reviewer for pushing me on this point, although more needs to be said.

14. An even more direct link between moral rules and Heaven might be established by an appeal to the idea of Heaven's mandate in the Mengzi. Because Mencius takes one's "proper fate," which for Mencius is decreed by Heaven, as involving certain absolute moral prohibitions, for instance, to never die as a criminal (Mengzi 7A2), it appears that certain divine commands are issued directly by Heaven, resembling in a way the Ten Commandments given by God in the Old Testament. I think the existence of such commands by either Heaven or God is compatible with a natural law theory, as long as such commands are not expressions of an arbitrary will but are connected to considerations of human 
flourishing grounded in human nature. The idea would be that the commands are made because following them is conducive to the human good. I thank P. J. Ivanhoe for this point.

15. One might wonder, then, whether a moral defect would be attributable to Heaven. But in Mencius's view, the lack of a moral sprout in someone is the result of individual failure or an improper environment. See Mengzi 6A7.

16. Irwin $(2006,326)$.

17. Along these lines, we might consider calling Mencius's account a "natural norm theory." I am sympathetic to this idea, and much depends on how we should understand the meaning of law, which is itself a very complex issue. But given a broader understanding of law, which I think is legitimate, we can reasonably describe Aquinas (and Mencius) as holding a natural law theory. I thank Michael Slater for raising this point.

18. Admittedly, the concept of moral obligation plays a much less prominent, and clearer, role in Mencius than in Aquinas. But as I noted above, I think Mencius endorses certain general obligations such as "Treat your elder as an elder" or "Cultivate the moral sprouts." And it is not implausible to think that for Mencius failing to carry out these obligations made one morally blameworthy.

19. It is worth noting that the early Confucians believed nonhuman animals also exhibited certain proto-moral tendencies and that later Confucians such as Zhu Xi held that they even fully possessed the virtues, while unable to fully express them because of the limits of their physical constitution $(q i)$. This issue played a pivotal role in the "Horak Debate" that began in eighteenthcentury Korea. See Kim (2015).

20. In this way, they differ from those naturalists (especially of the reductionist sort) who would understand human nature as a purely descriptive notion that is perhaps anchored in facts about what is statistically normal for human beings.

21. For such objections, see Woodcock (2006) and Andreou (2006).

\section{BIBLIOGRAPHY}

Ames, Roger. 2011. Confucian Role Ethics: A Vocabulary. Honolulu: University of Hawaii Press.

Andreou, Chrisoula. 2006. "Getting On in a Varied World." Social Theory and Practice 32 (1): 61-73.

Aquinas, Thomas. 2009. Treatise on Law: The Complete Text. Translated by Alfred J. Freddoso. South Bend, IN: St. Augustine's Press.

Cline, Erin M. 2013. "Religious Thought and Practice in the Analects." In The Dao Companion to Chinese Philosophy, edited by Amy Olberding, 259-91. Dordrecht: Springer.

Im, Manuel. 2011. "Mencius as Consequentialist." In Ethics in Early China: An Antbology, edited by Chris Frazer, Dan Robbins, and Timothy O'Leary. Hong Kong: Hong Kong University Press. 
Irwin, T. H. 2006. “Aquinas, Natural Law, and Aristotelian Eudaimonism.” In The Blackwell Guide to Aristotle's Nicomachean Ethics, edited by Richard Kraut, 323-41. Oxford: Blackwell.

Ivanhoe, Philip J. 2000. Confucian Moral Self Cultivation. 2nd ed. Indianapolis: Hackett.

- 2007. "Heaven as a Source for Ethical Warrant in Early Confucianism." Dao: A Journal of Comparative Philosopby 6:211-20.

Kim, Richard. 2015. "Human Nature and Animal Nature: The Horak Debate and Its Philosophical Significance." International Philosophical Quarterly 55 (4): 437-56.

Liu, Xiusheng. 2002. "Mengzian Internalism." In Essays on the Moral Philosopby of Mengzi, edited by Xiusheng Liu and Philip J. Ivanhoe, 101-31. Indianapolis: Hackett.

Murphy, Mark. 2011. "Natural Law Tradition in Ethics.” In The Stanford Encyclopedia of Philosophy, edited by Edward N. Zalta. http://plato.stanford .edu/entries/natural-law-ethics/.

Puett, Michael. 2002. To Become a God: Cosmology, Sacrifice, and SelfDivination in Early China. Cambridge, MA: Harvard University Asia Center.

Van Norden, Bryan. 2007. Virtue Ethics and Consequentialism in Early Chinese Philosophy. Cambridge: Cambridge University Press.

Indianapolis: Hackett.

Woodcock, Scott. 2006. "Philippa Foot's Virtue Ethics Has an Achilles' Heel.” Dialogue: Canadian Philosopbical Review 45 (3): 445-68.

Yu, Jiyuan. 2007. The Ethics of Confucius and Aristotle: Mirrors of Virtue. New York: Routledge. 